10. Алешинский, Е. С. Повышение конкуретноспособности железнодорожного транспорта за счет создания транспортно-логистических кластеров [Текст] / Е. С. Алешинский, В. В. Мещеряков, И. А. Лапушкин, Е. И. Рябовол // Восточно-Европейский журнал передовых технологий. - 2013. - Т. 5, № 3 (65). - С. 39-45. - Режим доступа: http://journals.uran.ua/eejet/article/view/18500

\section{Referenses}

1. The law of Ukraine "On railway transport" (2015). The Ministry of infrastructure of Ukraine. Available at: http://mtu.gov.ua/news/200.html?PrintVersion

2. Operator of railway rolling stock. ACADEMICIAN. Available at: http://official.academic.ru/

3. European railway reform - the main stages and key documents. Railways of the World. Available at: http:// 1430mm.ru/node/213

4. Alyoshinsky, E. S. ( 2012). The development strategy of regional transport systems on the basis of the formation of TLK Kharkiv region. Kharkiv: Department of innovative development of industry and transport structure, 17.
5. International experience of structural reforms in railway transport. BestReferat.ru. Available at: http://www. bestreferat.ru/referat-109381.html

6. Competitive Ukraine. Foundation "Effective Management". Available at: http://www.feg.org.ua/indexes/

7. Tsikhan, T. (2003). The cluster theory of economic development. Theory and practice of management, 5. Available at: http://www.subcontract.ru/Docum/DocumShow_DocumID_ 168.html

8. Transport and logistics clusters in the European Union. Available at: http://innocentr-samara.ru/files/Transportnologisticheskie\%20klastery\%20v\%20ES.pdf

9. Transport and logistics cluster in the Samara region. Available at: http://www.protown.ru/russia/obl/articles/articles_ 1073.html

10. Aleshynskyj, E. S., Meshherjakov, V. V., Lapushkyn, Y. A., Rjabovol, E. Y. (2013). Increasing of rail transport competitiveness by forming transportation and logistics clusters. Eastern-European Journal Of Enterprise Technologies, 5/3 (65), 39-45. Available at: http://journals.uran.ua/eejet/article/ view/18500

Дата надходження рукопису 11.08.2016

Алешинский Евгений Семенович, доктор технических наук, заведующий кафедры, кафедра транспортных систем и логистики, Украинский государственный университет железнодорожного транспорта, пл. Фейербаха, 7, г. Харьков, Украина, 61001

E-mail: aes-upp@mail.ru

Мещеряков Василий Владимирович, аспирант, кафедра транспортных систем и логистики, Украинский государственный университет железнодорожного транспорта, пл. Фейербаха, 7, г. Харьков, Украина, 61001

E-mail: vasyan98@ukr.net

Биловус Людмила Вячеславовна, Украинский государственный университет железнодорожного транспорта, пл. Фейербаха, 7, г. Харьков, Украина, 61001

UDC 331.47:377.44

DOI: 10.15587/2313-8416.2016.78573

\title{
POST-GRADUATE EDUCATION OF RESPONSIBLE STAFF ON LABOUR PROTECTION: PROBLEMS AND FEATURES
}

\author{
(C) R. Pahomov, E. Dyachenko, O. Zyma
}

The paper discusses the main problems of post-graduate education of managers and engineers and technical workers on labour protection. The necessity of responsible persons' studying is grounded. The effect of studying by staff and officials on labour protection problems in the workplace is reviewed. Structural and functional bases of studying of officials are studied. Analysis of the characteristics of the educational process is conducted. Different approaches and methods of studying are considered. Principles, the use of which can increase the efficiency of the studying process during the studying in the expert technical centers, are offered Keywords: advanced training, staff, studying process, principles of studying, labour protection

У статті розглядаються основні проблеми післядипломної освіти інженерно-технічних співробітників та керівників з питань охорони праці. Обумовлено необхідність навчання відповідних працівників. Розглянуто ефект проходження навчання співробітників та посадових осіб з питань охорони праці на робочому місиі. Досліджені структурні і функціональні засади навчання посадових осіб. Виконано аналіз характеристики освітнього процесу. Розглянуто різні підходи і методи навчання. Наведені принципи, використання яких може підвищити ефективність навчального процесу при навчанні в експертнотехнічних ичентрах

Ключові слова: підвищення кваліфікащії, персонал, навчальний процес, принципи навчання, охорона праџฺі 


\section{Introduction}

Improve the quality of knowledge, skills and acquirements on labour safety is still topical problem, especially in the dynamic socio-economic conditions of today. Lack of studying of officials in occupational safety and health is the cause of economic losses of enterprises and related with accidents and injuries. Sometimes it causes a full stop of production. In modern conditions of production, wherein reduction of economic losses are one of the main conditions of successful activity, neglecting of the discussed problem is unacceptable. One of directions to increase the effectiveness of the system of labour protection, along with the use of modern forms of education, is to perfect the professional studying system of managers and technical staff. Integral parts of this process are education and studying of officials.

\section{Literature review}

According to the documents [1, 2], officials, whose activity is connected with the organization of safe work at hiring and periodically, once every three years, have studying and testing in labour safety with the trade unions participation. Studying in labour safety for the officials is realized according to the typical thematic plan and training program. The system of labour protection is considered in the state standard [3] as separate properties of its components.

G. A. Varennya considered that the synergistic approach in the context of labour protection, including studying, as a relationship between the level of component-building systems and the level of its integrity. The synergistic model of effective functioning of the labour protection system is formulated in the paper [4].

Modern educational process includes three interrelated components that complement each other: education, socialization and culturation (Fig. 1). It is shown in $[5,6]$. Process and result of acquisition of professional knowledge (monodisciplinary and multidisciplinary) are preliminary related with education and, consequently, mastering process of the effective ways of solving professional tasks.

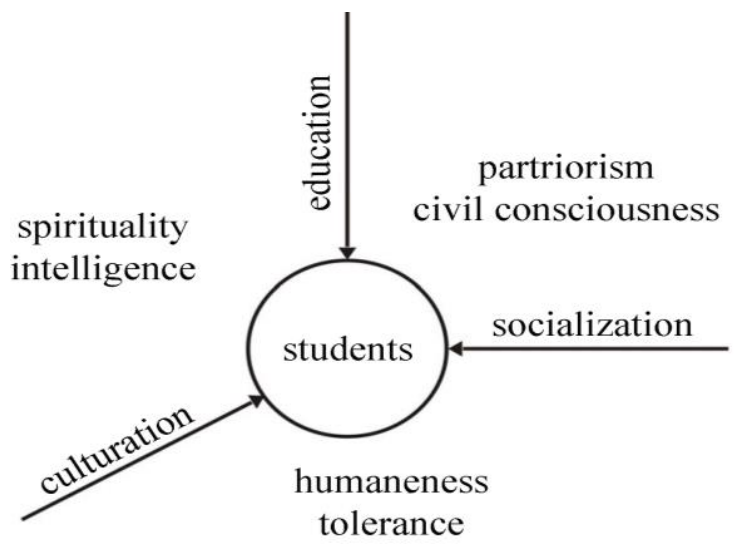

Fig. 1. Modern educational process: three-axis fragment of global information space

Under socialization we understand the process of assimilation (and its result) and active playback of indi- vidual socio-cultural experience (social norms, values, patterns of behavior, roles, attitudes, customs, cultural traditions, collective representations, beliefs, etc.). According to socialization, a person learns the society values system and this allows it to operate successfully as a member of society.

The term "culturation" means human educational process (and its result - the formation of different personality traits) of traditions and norms of behavior in a particular culture at a particular stage of its historical development.

Despite of the large number of solved educational problems in recent researches, problems about the effectiveness of these approaches in a separate direction arise - the certification studying of specialists and technical workers on labour protection, as this process is specific and, in some cases, is unidirectional. It should be noted that educational problems in integral and certification studying of officials were not considered.

\section{Aim and research problems}

The aims of this work are analysis of structural and functional principles of officials and experts studying on labour protection, search the directions to increase its efficiency in modern conditions and building domainstructure system of education.

Research problems: to formulate basic principles, which can significantly increase postgraduate education efficiency on labour protection of responsible staff; to identify the features, which require a particular approach to studying the staff.

\section{Presentation of the main material of post- graduate education of responsible staff on labour pro- tection}

Managers and specialists of labour protection services, factories, committee members of knowledge testing on labour protection, technical experts on industrial safety, heads of departments and lecturers of the labour protection departments of higher education institutions, specialized managers of educational centers and staff study in the State Labour Service of Ukraine.

The aim of the educational process is knowledge and skills enrichment in various activities, related to the area of employment and development of professional and personal specialist. Because of the studying of already established professionals on certification courses, educational process has several features that allow to consider postgraduate education as a tool for socio-economic transformation and the way of specialists adapting to the new conditions. An important feature of postgraduate education is the next: model of educational process often involves the responsibility of the learner for the definition of the educational area, selection of methods and educational process planning. At the same time teacher is only a process coordinator.

Impact of the old teacher training scheme on adult established professionals (focus on the finished knowledge learning, theoretical knowledge separation from practice and lecture form of classes) is one of the important issues. Domain-disciplinary model of learn- 
ing is firmly set in the curriculum: content and structure, timing, labouriousness features, didactic description (Fig. 2).

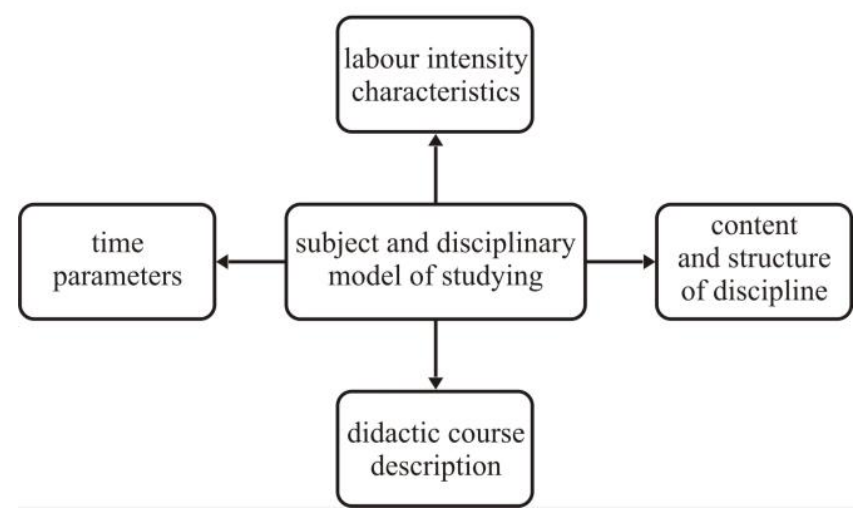

Fig. 2. Orientation on education resource parameters

The most complex technology corresponds to traditional studying method - through remembering, the direct result - learning process and skills acquiring are extremely low. This type of studying is extensive, so it takes a lot of time, health and resources. Overuse amount of nonfinite and nonsystematic information is useless. It overloads the memory of the audience; this is the cause of premature fatigue and trainees' mental abilities reduce.

The above traditional form of education on labour protection functions as a closed system that eliminates its ability to further improvement. Nowadays we understand that we must focus studying not on education resource parameters, but on its results. The studying process should be done creative in modern education because of non-linear process nature.

In addition, there must be taken age, psychological, professional, social, and a host of other features during education of adults. At the same time, some of the adults' experience difficulties in studying are associated with some change's unavailability and a number of psychological reasons. Therefore, during planning and carrying out the educational process it is necessary to use specific and innovative approaches. Knowles M.Sh. formulated fundamental principles of adult learning theory [7]:

- leading role in their own learning belongs to adult learner;

- adult tends to self-realization, self-reliance, selfcontrol;

- adult has a life experience, which can be used as an important source of education;

- adult learns to solve important life problems and to achieve a specific goal;

- adult expects for immediate knowledge and use of the skills;

- adult studying activities associated with temporal, dimensional, domestic, professional, social factors that limit studying process or facilitate it;

- adult studying process takes place in the form of joint activity with the lecturer at all stages: planning, implementation, correction, assessment.

These basic features of adult studying are significantly different from the approaches of traditional pedagogy. Approach to theoretical knowledge is change. Studying directions that include integrated material in several related disciplines (interdisciplinary) take the lead to the forefront. In addition, approaches to cooperation with studying persons, methods of communication, responsibility for the distribution of the same motivation to studying are different. Adults, who are actively involved in studying, bring to the learning process their own experience, trying to match educational information with their goals and objectives. Adult professionals learn new skills with different rates, so it is necessary to pay special attention to the individualization of the educational process during the work with them.

In this case, the lecturer is an expert and psychologist. Presentation of the new material is not the main part of his activities; he provides the creative part of the learning process. It is important to emphasize on the key factor in the process of learning as a synergism (cooperation) and the lecturer's individually communication with all students, using various forms of employment during the educational process.

\section{Research results}

Due to the above features of postgraduate education, the basic principles that can significantly increase its efficiency are formulated [4, 8-10].

1. The principle of priority of self-studying. This principle provides an opportunity for adults to leisurely introduction of educational information, learning the terms, concepts, classifications, understanding the processes and technologies of their implementation. Modern distance education greatly helps in this case. Individual work is the mutual exchange of information between the lecturer and the learner. Formalization of empirical knowledge is done at this time.

2 . The principle of coherent knowledge associated with the use of coherent (collective) knowledge, which occurs at the time of collective creativity of learners. All participants in the educational process are equitable part-owners.

3. The principle of using the life experience (especially social and professional), practical knowledge and skills as a learning base and the sources of formalization of new knowledge.

4. The principle of adjusting of outmoded experience and personal attitudes that prevent the learning of new knowledge. In such cases, it is the necessary to use conversations, beliefs, forming new perspectives, opening new prospects.

5. The principle of individual approach based on individual needs, taking into account the social and psychological characteristics and the constraints imposed by its activities, the availability of free time, financial resources and technical capacity. The basis of individual approach is rating of the learner, the analysis of professional activity, social status and the nature of relationships in the collective. Implementation of previous surveys, questionnaires, testing can create social and psychological portrait of personality. Paying attention to individuality, we must note that in labour protection system there are some work rules, regulations, instructions and other documents. Knowledge, accurate performance 
and the use of ability are the obligated requirement, as for officials and for workers.

6. The principle of elective learning. It consists of giving to the person, which studies the agency objectives, content, form, sources, tools, time, place for study and evaluation of results.

7. The principle of reflectivity. This principle lies in conscious attitude to education that is a major part of self-motivation in its own case.

8. The principle of demand studying results for practice. According to this principle, before the planning and organization of learning it is necessary to conduct the study and analysis of the activities that will articulate the purpose and aims of learning.

9. The principle of systematic studying. It consists in regularity, continuity of learning based on the results of previous studies and new needs.

10. The principle of learner's progress. Improving the person in overall, creating capacity for selflearning, learning new in the practice life of human aimed to studying.

\section{Conclusions and suggestions}

Due to the above, postgraduate education of officials and experts on labour protection, which undoubtedly greatly effects on the improvement quality of the system of labour protection, has several significant features that require the use of a fundamentally different approach to the educational process. According to the above, these principles allow in some measures to take into account of features, specificity and efficiency of the studying process on certification courses, among which we should highlight next ones:

a) the principle of priority of self-studying;

b) the principle of using the life experience, practical knowledge and skills as a learning base and the sources of formalization of new knowledge;

c) the principle of adjusting of outmoded experience and personal attitudes that prevent the learning of new knowledge;

d) the principle of demand studying results for practice.

\section{References}

1. Zakon Ukrainy "Pro ohoronu patci" vid 14.10 .1992 roku (zi zminamy vid 16.10.2012 roku № 5459 - VI) [Electronic resource]. - Derzhava i pravo - Elektronna biblioteka. 2013. - Available at: http://statelaw.pp.ua/закон-україни-проохорону-праці

2. Typove pologennyapro poryadok navchannya I perevirky znanz pytanokhorony pratci (NPAOP0.00-4.12-05). 26.01.2005 roku № 15 (zi zminamy vid 16.11.2007 roku № 273) [Text]. - Derzhavnyj Komitet Ukrai'ny z nagljadu za ohoronoju praci, 2007. - № 273. - Available at: http://zakon4. rada.gov.ua/laws/show/z0231-05

3. DSTU 2293-99 "Okhorona pratci. Terminy ta vyznachennya osnovnyx ponyat" [Text]. - Vvedenyi $\mathrm{v}$ diyu nakazom Dergavnogo komitety Ukrainy po standartyzacii, metrologii ta sertyfikacii vid 26.03.1999 r. № 164 . Chynnyi vid $01.01 .2000 \mathrm{r}$.
4. Varennya, G. A. Sekretnyi kod, abo Yak pidvyschyty efektyvnist funkcionuvannya systemy okhorony pratci [Secret code or How to increase the efficiency of the labour protection system functionality] [Text] / G. A. Varennya. - Kyiv: Osnova, 2009. - 364 p.

5. Smirnov, V. A. Informatcionnaya pedagogika [Informational pedagogic]. B. 2 [Text]: monografiya / V. A. Smirnov, T. P. Varlamova, I. S. Eremina, L. P. Efimova et. al. // Teoriya, metodika i organizaciya pedagogicheskoi raboty [Theory, method and organization of pedagogical work]. - Novosibirsk:“SIBPRINT", 2010. - $250 \mathrm{p}$.

6. Smirnov, V. A. Osnovni zakony informatciinoi pedagogiky [Basic laws of the informational pedagogy] [Text] / V. A. Smirnov // Pedagogical sciences: theory, history, innovative technologies. - 2011. - Issue 2 (12). - P. 80-91.

7. Innovatsionno-obrazovatelnie tekhnologii I effectivnaya organizatciya uchebnogo processa v medicinskom vuze [Innovative educational technology and effective organization of educational process in medical high school] [Text] / S. Yu. Nikulina (Ed.) // Vuzovskaya pedagogika. - Krasnoyarsk: Verso, 2011. -477 p.

8. Zmeev, S. I. Tekhnologiya obucheniya vzroslux [Adult learning technology] [Text] / S. I. Zmeev. - Moscow: Publishing Center "Academy", 2002. - 126 p.

9. Skakyn, V. A. Organizaciya I metodika professionalnogo obycheniya [Organization and methods of professional studying] [Text]: uchebnoe posobie / V. A. Ska-kyn. - Moscow: Forum: INFRA, 2007. $-336 \mathrm{p}$.

10. Romanchuk, A. A. Menedgment okhrani truda [Labour safety management] [Text] / A. A. Romanchuk. - Kyiv: Osnova, 2003. - 176 p.

\section{References}

1. Zakon Ukrainy "Pro ohoronu patci" vid 14.10.1992 roku (zi zminamy vid 16.10.2012 roku № 5459 - VI) (2013). Derzhava i pravo - Elektronna biblioteka. Available at: http://statelaw.pp.ua/закон-україни-про-охорону-праці

2. Typove pologennyapro poryadok navchannya I perevirky znanz pytanokhorony pratci (NPAOP0.00-4.12 -05). 26.01.2005 roku № 15 (zi zminamy vid 16.11.2007 roku № 273) (2007). Derzhavnyj Komitet Ukrai'ny z nagljadu za ohoronoju praci, 273. Available at: http://zakon4.rada.gov.ua/ laws/show/z0231-05

3. DSTU 2293-99 "Okhorona pratci. Terminy ta vyznachennya osnovnyx ponyat" (1999). - Vvedenyi v diyu nakazom Dergavnogo komitety Ukrainy po standartyzacii, metrologii ta sertyfikacii vid 26.03.1999 r. № 164. Chynnyi vid $01.01 .2000 \mathrm{r}$.

4. Varennya, G. A. Sekretnyi kod, abo Yak pidvyschyty efektyvnist funkcionuvannya systemy okhorony pratci [Secret code or How to increase the efficiency of the labour protection system functionality] (2009). Kyiv: Osnova, 364.

5. Smirnov, V. A., Varlamova, T. P., Eremina, I. S., Efimova, L. P. et. al. (2010). Informatcionnaya pedagogika [Informational pedagogic]. B. 2. Teoriya, metodika i organizaciya pedagogicheskoi raboty [Theory, method and organization of pedagogical work]. Novosibirsk:"SIBPRINT", 250.

6. Smirnov, V. A. (2011). Osnovni zakony informatciinoi pedagogiky [Basic laws of the informational pedagogy]. Pedagogical sciences: theory, history, innovative technologies, 2 (12), 80-91.

7. Nikulina, S. Yu. (Ed.) (2011). Innovatsionno-obrazovatelnie tekhnologii I effectivnaya organizatciya uchebnogo processa $\mathrm{v}$ medicinskom vuze [Innovative educational technol ogy and effective organization of educational process in me- 
dical high school]. Vuzovskaya pedagogika. Krasnoyarsk: Verso, 477.

8. Zmeev, S. I. (2002). Tekhnologiya obucheniya vzroslux [Adult learning technology]. Moscow: Publishing Center "Academy", 126.
9. Skakyn, V. A. (2007). Organizaciya I metodika professionalnogo obycheniya [Organization and methods of professional studying]. Moscow: Forum: INFRA, 336.

10. Romanchuk, A. A. (2003). Menedgment okhrani truda [Labour safety management]. Kyiv: Osnova, 176.

Рекомендовано до публікації д-р техн. наук Нижник О. В. Дата надходження рукопису 19.08.2016

Pahomov Roman, PhD, Associate Professor, Department of engineering management and technology and occupational safety, Yuri Kondratyuk Poltava National technical University, Pershotravneviy ave., 24, Poltava, Ukraine, 36000, E-mail: pahomov_ri@mail.ru

Dyachenko Eugeny, PhD, Associate professor, Department of engineering management and technology and occupational safety, Yuri Kondratyuk Poltava National technical University, Pershotravneviy ave., 24, Poltava, Ukraine, 36000, E-mail: eugeny1210@gmail.com

Zyma Oleksandr, PhD, Associate professor, Department of engineering management and technology and occupational safety, Yuri Kondratyuk Poltava National technical University, Pershotravneviy ave., 24, Poltava, Ukraine, 36000, E-mail: zymaae@gmail.com

УДК 681.5(042.3)

DOI: 10.15587/2313-8416.2016.78581

\title{
ТОПОЛОГІЧНИЙ СИТУАЦЙНИЙ АНАЛІЗ ТА СИНТЕЗ СТРАТЕГІЙ УПРАВЛІННЯ ОБ'ЄКТОМ В УМОВАХ КОНФЛІКТУ, НЕВИЗНАЧЕНОСТІ ПОВЕДІНКИ ТА ВАРІАТИВНОЇ МНОЖИНИ ОБ'ЄКТІВ СПОСТЕРЕЖЕННЯ
}

\author{
(C) В. В. Семко
}

Розглянуто конфлікт взаємодії об'єктів в просторі спостереження як иілісне явище з певним розмаӥттям типів зв'язків між його елементами, об'єктами, системами, зовнішнім середовищем, що зведені в єдину теоретичну концепцію та різнобічно і глибоко визначають реальні особливості об'єкта досліджень. При дослідженні використано методологію системно-структурного аналізу конфлікту, як дослідження явища в иілому, та системно-функиіонального аналізу, як дослідження з метою визначення усіх основних взаємозв'язків із зовнішнім середовищем

Ключові слова: конфлікт, об’єкт, простір спостереження, концепція, аксіома, система інтелектуального управління, модель

The conflict of cooperation of objects is considered in observation space as integral phenomenon with the certain variety of types of connections between its elements, objects, systems and environment that erected in a single theoretical conception and comprehensively and deeply determine the real features of object of researches. Methodology of system-structural analysis of conflict is used as research of the phenomenon in the whole and system-functional analysis as research with the aim of determination of all basic intercommunications with an environment

Keywords: conflict, object, observation space, conception, axiom, intellectual management system, model

\section{1. Вступ}

В загальному випадку під конфліктом розуміють ситуацію, в якій кожна зі сторін намагає ться зайняти позицію несумісну з інтересами іншої сторони.

При аналізі конфліктів в технічних системах [1-5] конфлікт визначається як взаємодія об'єктів (технічних систем), що мають несумісні цілі і способи їх досягнення, діяльність яких так чи інакше пов'язана з постановкою і рішенням завдань управління, 3 прогнозуванням і прийняттям рішень, а також $з$ плануванням цілеспрямованих дій.

Дослідження та аналіз поведінки об'єктів (учасників) конфлікту здійснюється за методологією системного аналізу, як напрямку методології наукового пізнання, в основі якого лежить розгляд об'єктів як систем. При дослідженні конфлікт розглядається як цілісне явище 3 певним розмаїттям типів зв'язків між його елементами, об'єктами, системами, зовнішнім середовищем, тощо, які мають бути зведені в єдину теоретичну концепцію, що різнобічно і глибоко відбиває реальні особливості явища конфлікту, яке досліджується [3, 4, 5-9].

При дослідженні конфліктів в технічних системах доцільним є застосування:

- системно-структурного аналізу конфлікту, як дослідження явища в цілому, яке складається 3 системи підструктур, які, у свою чергу, складаються 3 елементів, і в якості підсистем входить в систему більш високого рівня;

- системно-функціонального аналізу конфлікту, як дослідження з метою визначення всіх основних взаємозв'язків конфлікту із зовнішнім середовищем, в якому конфлікт розвивається, у виявленні характеру і способів впливу одних елементів і підструктур конфлікту на інші (біфуркаціі). 